\title{
DIASPORA DAN PEMBENTUKAN IDENTITAS ETNIS ARAB DI KOTA MANADO
}

\section{DIASPORA AND ETHNIC IDENTITY FORMATION OF THE ARABS IN MANADO}

\author{
Muhammad Nur Ichsan Azis \\ Balai Pelestarian Nilai Budaya Sulawesi Utara \\ Jln. Katamso, Bumi Beringin Lingkungan V, Kelurahan Wenang, Kecamatan Wanea, \\ Kota Manado, Sulawesi Utara, Indonesia \\ icchankazis19@gmail.com
}

Diterima tanggal 24 Januari 2020

Disetujui tanggal 24 November 2020

\begin{abstract}
This paper describes the Arab people in Manado, as ethnic groups, traders and influential people in the late 19th century to the early 20th century. The Arabs were classified as people who are active in trading activities, especially in the shift of commodities, until the mid-20th century. They were one of the ethnic groups that play several important roles in the structure of Indonesian society, including in Manado. These activities influenced the process of population movement, diaspora, identity formation, and the axis of commercial networks towards the beginning of the 20th century. Manado was a strategic area that connected several major and small cities for Arab traders. This paper used historical methods to examine Arab communities that still survive today. The diaspora of the Arabs to Manado strengthen the Arabs in Indonesian archipelago. The network that was formed had an impact on the religious identity attached to the Arabs in Manado towards the early 20th century AD. One offactors driving the power of the Arabs was the economy which can take advantage of the space among other business actors. As a result, they became a new force in the early 20th century that they were able to attract local people's attention to stay connected.
\end{abstract}

Keywords: Arab, diaspora, migration, and colonial.

ABSTRAK
Tulisan ini mendeskripsikan orang-orang Arab di Manado, baik sebagai etnis, pelaku niaga,
hingga orang yang berpengaruh pada akhir abad ke-19 hingga awal abad ke-20. Etnis Arab
tergolong masyarakat yang aktif dalam kegiatan perdagangan, terutama pada perpindahan
komoditas hingga pertengahan abad ke-20. Mereka menjadi salah satu etnis yang memainkan
beberapa peran penting dalam struktur masyarakat Nusantara, termasuk di Manado. Aktivitas
tersebut memengaruhi proses perpindahan penduduk, diaspora, pembentukan identitas, dan
poros jejaring niaga menjelang awal abad ke-20. Manado menjadi kawasan strategis yang
menghubungkan beberapa bandar utama dan kecil untuk para pedagang Arab. Tulisan ini
menggunakan metode sejarah untuk meneliti komunitas Arab yang masih bertahan sampai 
sekarang. Diaspora etnis Arab ke Manado mendorong kekuatan orang-orang Arab di Nusantara. Jejaring yang terbentuk berdampak pada pembentukan identitas agama yang melekat pada etnis Arab di Manado menjelang awal abad ke-20 M. Salah satu faktor pendorong kekuatan etnis Arab adalah perekonomian yang mampu memanfaatkan ruang di antara para pelaku niaga lainnya. Akibatnya, mereka menjadi kekuatan baru di awal abad ke-20 yang mampu menarik perhatian penduduk setempat untuk tetap menjalin relasi.

Kata kunci: Arab, diaspora, migrasi, dan kolonial.

\section{A. PENDAHULUAN}

Diskursus mengenai etnis di Indonesia kembali mencuat setelah persoalan politik identitas dan etnis yang menyeruak pada tahun 2017. Kasus tersebut memperparah kondisi politik identitas yang terjadi di Indonesia di masa reformasi. Demokrasi dan moderasi keberagamaan serta keragaman mengalami masa krisis yang berakibat pada persinggungan di tengah masyarakat. Isu SARA terus digaungkan, kepercayaan terhadap sesama warga negara tergerus, bahkan terjadi pengelompokan masyarakat berdasarkan etnis dan agama. Hal semacam ini sebenarnya pernah terjadi di masa lalu ketika pemerintah kolonial membagi penduduk di Nusantara menjadi tiga kelas: Eropa, Timur Asing, dan Pribumi pada abad ke-19. Dampaknya terjadi pengelompokan dan jarak antara penduduk pribumi dengan penduduk lainnya sampai awal abad ke-20 M.

Kehadiran dua kelompok pertama tersebut di Nusantara bermula dari perniagaan rempah. Seperti dinyatakan dalam tesis Turner (2011:xv-xx) bahwa rempah-rempah memiliki nilai jual lebih di kawasan Laut Tengah dan di beberapa kekaisaran kuno, daerah asal kelompok-kelompok tersebut. Rempah-rempah telah dikenal sejak era sebelum Masehi di mana tercatat rempah-rempah, terutama pala, cengkih, dan tembakau pernah dijadikan sebagai pengawet jenazah di Mesir dan Italia. Adapun bagi kekaisaran Inggris, rempah menjadi salah satu bumbu dapur untuk hidangan makanan, bahkan lebih jauh lagi rempah-rempah dikatakan memiliki "aroma magis" untuk persembahan para dewa-dewi di Yunani. Oleh karena itu, setidaknya rempah-rempah bukanlah barang baru di kawasan Laut Tengah yang pada awal abad ke-15 menjadi buruan utama masyarakat Eropa, terutama Portugis dan Spanyol. Perkenalan rempah-rempah tersebut dibawa oleh pedagang dari Timur Tengah, tidak terkecuali Arab, yang membawanya ke Laut Tengah dan berdampak pada pembukaan jalur perdagangan maritim di masa kemudian.

Tidak sekedar berdagang, tetapi juga bermukim, kedua kelompok tersebut hadir dalam peristiwa sejarah yang menyinggung persoalan agama dan etnis. Persoalan yang selalu menarik untuk dijadikan tema kajian. Di salah satu kawasan timur Nusantara, 
Manado, memiliki sejarah panjang mengenai hubungan antar-agama. Persoalan ini selalu diidentikkan bahwa Manado adalah "koloni setia" bagi pemerintah Hindia Belanda. Bukti literatur banyak yang menghubungkan Manado sebagai basecamp Pemerintah kolonial Belanda setelah Ambon. Di sisi lain, kebijakan penyebaran agama, dan perekonomian yang berlaku di Manado semakin menguatkan bahwa pemerintah kolonial merasa Manado sebagai tempat yang tepat baginya. Misalnya Graafland (1991) menyebutkan bahwa Manado sebagai salah satu wilayah yang cukup strategis untuk pemerintah kolonial. Kunjungannya ke Manado pada pertengahan abad ke-19 M menuliskan bahwa masyarakat Manado (dan juga Minahasa), merupakan salah satu pilar terselenggaranya pemerintahan yang baik.

Selain persoalan agama, keberadaan kedua kelompok tersebut juga kerap dibicarakan dalam persoalan ekonomi. Laporan Moelsbergen (1829:7) menunjukkan bahwa para pedagang Arab, bersama dengan pedagang lainnya menjadi kelompok perantara komoditas niaga di Semenanjung Laut Sulawesi. Pedagang Arab membeli beras dan menyuplai rempah-rempah. Di Manado, para pedagang Arab membeli beras dari orang-orang Minahasa dan membawanya ke Ambon. Bahkan pada akhir abad ke-19 dan awal abad ke-20, mereka juga menyuplai kelapa dan kopra ke beberapa kawasan di daratan
Sulawesi dan Kepulauan Maluku (Henley 2005:87).

Aktivitas maritim pedagang Arab pada masa cukup aktif sejak abad ke-13 (Azra 2013:206). Mereka menjalankannya sebagai pelaut peniaga yang mengumpulkan dan menyuplai komoditas ke kawasan bandar utama. Praktik ini berdampak pada pembentukan relasi, meskipun pada skala kecil hanya melibatkan persoalan keuntungan dan kerugian dalam menjalankan perniagaan (Poelinggomang 2012:1-3).

Namun ada hal lain yang mendorong perkembangan Manado sebagai salah satu kawasan strategis di Nusantara. Praktik perekonomian yang dibangun oleh para pedagang merupakan bagian yang terintegrasi dalam memosisikan Manado sebagai kawasan strategis. Pedagang Arab jarang disebut dalam sumber-sumber Manado kontemporer, namun pada beberapa laporan pemerintah kolonial para pedagang Arab menjadi pedagang yang aktif menyuplai ke pemerintah Belanda di Manado. Bukti lain yang menguatkan adalah warisan para pedagang Arab yang membangun Kampung Arab di sebelah timur Benteng Nieuwe Amsterdam atau sisi selatan Sungai Tondano. Kawasan tersebut berada di antara Kampung Islam dan Kampung Cina pada abad ke-19.

Dalam laporan Berg (2010), dia lupa melaporkan pengaruh orang-orang Arab di Sulawesi. Dia hanya menuliskan secara kuantitas jumlah 
Handep Jurnal Sejarah dan Budaya Vol. 4, No. 1, Desember 2020, hlm. 61-86

penduduk Arab dan keturunannya tanpa memberikan deskripsi mengenai kondisi mereka. Surat dari J.G.F. Riedel kepada kepala residen di Manado (ANRI 1875:No. 946) justru menyebutkan mengenai jejak orang Arab di Manado. Riedel (1850) mengelompokkan orang Arab sebagai burgers, sebagaimana yang disebutkan oleh Valentijn (1724) sudah menemukan bahwa di kawasan pesisir utara Pulau Sulawesi terdapat kelompok orang Arab, meskipun identifikasi tersebut masih terbatas. Bahkan, mereka mengunjungi Manado hanya tujuan untuk berniaga. Sistem angin laut dan darat dimanfaatkan untuk melanjutkan perjalanannya ke Maluku. Walau demikian, mereka aktif dan mampu menjaga hubungan niaga serta rutin mengunjungi Manado.

Perkembangan dan pengaruh pedagang Arab di Manado terus berlanjut hingga menjelang abad ke-19 M. Pada abad ke-19 M, masa niaga memasuki dinamika baru. Terjadi pergeseran yang cukup signifikan, termasuk di Manado, ketika beberapa komoditas berhasil dimonopoli pemerintah kolonial. Poros niaga dari dan menuju Manado semakin ramai. Peningkatan ini terlihat ketika Vickers (2013:20) menyebut bahwa suplai komoditas terus bergerak ke kawasan bandar-bandar utama.

Salah satunya laporan dari Van den Berg yang menuliskan keadaan orang Arab di Nusantara. Pada kasus Manado, Berg menuliskan setidaknya terdapat 36 orang Arab dan keturunan-nya yang bermukim hingga pertengahan 1850an. Selain Berg, Riedel juga menuliskan bahwa peran ekonomi pedagang Arab mempercepat proses diaspora dan migrasi mereka ke kawasan Timur Nusantara, termasuk di Manado. Sebagaimana Robert Cohen (2008:1-2) mengungkapkan bahwa proses diaspora masyarakat dapat ditelusuri melalui empat konsep. Pertama, konsep klasik yang dilatarbelakangi oleh faktor keagamaan; kedua, oleh faktor politik, dan pengalaman sejarah; ketiga, konstruk masyarakat yang memiliki keterikatan satu sama lain; keempat penggabungan dari tiga faktor sebelumnya yang menjadi pola utama dalam proses diaspora pada abad ke-19 M. Singkatnya, diaspora dilakukan oleh kelompok atau individu yang tersebar dan berpencar dengan alasan tertentu dan mungkin sepenuhnya tidak melakukan asimiliasi ataupun akulturasi di tanah tujuan (Ember et al. 2005:xxvi).

Orang Arab yang mengunjungi Manado tidak dapat dilepaskan dari proses ekonomi dan persoalan untungrugi perniagaan rempah-rempah. Di sisi lain, keuntungan lainnya adalah proses Islamisasi yang mampu tersebar di beberapa kawasan strategis. Mereka tersebar ke berbagai wilayah di Nusantara dengan tujuan Maluku untuk memperoleh rempah-rempah. Kemudian mereka membentuk jejaring perniagaan melalui aktivitas ekonomi, hingga mampu menyuplai komoditas ke Timur Tengah. Kompetisi yang berlangsung selama masa niaga 
menempatkan pedagang Arab sebagai kelompok yang mudah memengaruhi penduduk lokal melalui kedekatan agama (Cabaton 2014:174-175).

Akan tetapi pola pendekatan tersebut berbeda dengan praktik yang berlangsung di Manado sebab para pedagang Arab menjalin relasi dengan masyarakat tidak menggunakan kedekatan agama dan kekuatan politis, melainkan dengan aktivitas niaga dan ekonomi maritim. Orang Arab pada awalnya menjalin hubungan niaga dengan menjadi pembeli komoditas beras yang diproduksi di Manado. Relasi tersebut berlanjut hingga para pedagang Arab menjadi penyuplai komoditas rempah-rempah dari Maluku ke Manado, serta peran ekonomi tersebut berlanjut sebagai pemilik modal dan lahan kelapa di wilayah Keresidenan Manado. Pembentukan relasi niaga dan sosial terbentuk yang diikuti dengan proses diaspora dan migrasi para pedagang Arab di Manado dengan memanfaatkan kekuatan ekonomi dan niaga maritimnya. Para pedagang Arab mampu menjalin relasi dengan penduduk Manado tidak dengan memanfaatkan kedekatan agama, melainkan memanfaatkan jalur maritim yang terbentuk melalui distribusi dan suplai komoditas di jalur rempah.

Keberadaan orang Arab di Nusantara identik dengan proses diaspora. Dalam praktiknya, diaspora dihubungkan dengan kondisi masyarakat di wilayah asalnya. Faktor ekonomi menjadi salah satu jalur diaspora Arab ke Nusantara. Mereka berdagang sekaligus berdakwah untuk mengenalkan, menyebarkan, dan mengajarkan Islam (Burhanudin 2014:187-188). Di sisi lain, representasi orang Arab di Nusantara berdiaspora dengan pola nomaden di kawasan pesisir. Mereka memperkuat posisinya dengan cara menjalin relasi sosial, ekonomi, hingga politik dan terlibat langsung pada aktivitas perekonomian penduduk pribumi. Pada kasus orang Arab, mereka menetap di daerah luar, "overseas/away", seperti yang terjadi di Nusantara pada abad ke-19 M, termasuk di Manado, sebagai pelaku diaspora (Freitag 2009:20-21).

Efek panjang dari usaha tersebut terlihat pada berdirinya permukiman sementara bagi orang-orang Arab. Mereka membentuk nucleus identitas pedagang Arab di kawasan pesisir. Keterikatan tersebut sebagaimana yang diungkapkan oleh Van Leur (2015:9) sebagian ekspansi kapitalisme. Praktik ini berusaha menjalankan sistem perdagangan yang teratur. Tujuan dari usaha ini yakni menampilkan reformasi struktur ekonomi dan masyarakat yang terlibat di dalamnya.

Tujuan dari tulisan ini berusaha menampilkan aktivitas diaspora orangorang Arab di Manado. Mereka, orangorang Arab, berdiaspora, membentuk jejaring, komunitas etnis, hingga perkampungan untuk mendukung aktivitas niaganya pada abad ke-19 di sekitar bandar Manado. Mereka juga memanfaatkan jalur niaga maritim melalui perpindahan komoditas, baik distribusi dan konsumsi untuk 
Handep Jurnal Sejarah dan Budaya

Vol. 4, No. 1, Desember 2020, hlm. 61-86

kepentingan ekonomi dan sosialnya, hingga tetap menjalin relasi penduduk di sekitar pesisir Manado.

Persoalan di Manado di masa niaga maritim menjadi kompleks ketika para pedagang Arab berdiaspora. Dengan demikian, permasalahan diaspora etnis Arab menarik untuk dikaji. Bagaimana kondisi Manado ketika etnis Arab membentuk komunitas di Keresiden Manado? Bagaimana proses diaspora etnis Arab di Keresiden Manado? Mengapa etnis Arab memilih Keresiden Manado?

Kajian mengenai keberadaan orang-orang Arab di Manado, khususnya yang berkaitan dengan aktivitas mereka selama abad ke-19 ternyata masih kurang. Sumber yang dapat dijadikan sebagai tinjauan pustaka untuk melihat keberadaan orang Arab di Manado dapat ditemukan melalui tulisan Graafland (1991), Lapian (2009), Moelsbergen (1928), Berg (2010), serta Azis (2019).

Berg (2010) menunjukkan bahwa orang Arab di Nusantara mampu menunjukkan bahwa peran dan pengaruh orang-orang Arab di Nusantara cukup besar, terutama dalam proses diaspora, relasi, hingga niaga pada abad ke-19 M. Graafland, Lapian, hingga Moelsbergen hanya menunjukkan bahwa orang-orang Arab pada masa itu disebut aktif sebagai pedagang semata dengan membuat permukiman sementara di pesisir Teluk Manado hingga Sungai Tondano. Tetapi dari beberapa kajian di atas tidak satupun yang mengkaji secara khusus mengenai orang-orang Arab di Manado, kecuali tesis karya Azis. Pada tesis tersebut, Azis (2019) mengajukan temuan tentang aktivitas ekonomi para pedagang Arab di kawasan pesisir Manado sebagai bagian dari kelompok niaga dalam jalur perdagangan komoditas rempah-rempah. Adapun artikel ini difokuskan pada pembahasan diaspora, migrasi, dan pembentukan identitas agama pada etnis Arab di Manado.

Di sisi lain, Berg tidak banyak mencatatkan mengenai peran orangorang Arab di Manado dan hanya menuliskan jumlah kuantitas orang Arab, tanpa memberikan penjelasan yang berarti kecuali sebagai pedagang. Padahal apabila merujuk pada kondisi masyarakat di Manado pada abad ke-19, kawasan tersebut cukup ramai dan kompleks untuk didiami sebagai daerah penghubung rempah-rempah dan komoditas lainnya. Di sisi lain, Manado tidak hanya sebagai daerah penghubung niaga, tapi juga sebagai kawasan terbuka untuk para pendatang yang dibuktikan melalui munculnya kelompok etnis yang berperan di Manado pada akhir abad ke-19 sampai awal abad ke-20. Oleh karena itu, penulis kemudian berupaya untuk mendeskripsikan kembali orang-orang Arab melalui proses diaspora hingga pembentukan identitas etnis pada akhir abad ke-19.

Kajian dari Safran (1991:97) mengenai diaspora menarik untuk menunjukkan aktivitas orang-orang Arab di Manado. Diaspora yang 
dimaknai sebagai sebuah proses untuk membangun, membentuk, dan mempertahankan keberadaan melalui aktivitas berpindah dengan tujuan memperoleh tempat baru yang nyaman dan aman. Di sisi lain, diaspora juga sebuah usaha untuk mentransmisikan kebudayaan melalui asimilasi dan akulturasi antar-masyarakat. Bahkan lebih jauh, diaspora memperkuat hubungan, relasi, dan jejaring antara daerah asal dan tempat tujuan. Selain Safran, Cohen, dalam Santoso (2014:4) mengungkapkan bahwa diaspora berimplikasi timbal-balik bagi masyarakat. Proses ini merupakan bagian panjang dalam aktivitas masyarakat yang berpindah, hingga menjadi satu "bagian" masyarakat. Meskipun tidak dapat digeneralisasi, diaspora juga berdampak pada proses migrasi penduduk, seperti yang dilakukan oleh orang-orang Arab di Manado, melalui relasi dan jejaring niaga. Rempah-rempah dan komoditas niaga menjadi penghubung dari adanya dispora yang terjadi dan faktor keterbukaan masyarakat juga yang membuat orang-orang Arab tetap bertahan di Manado.

\section{B. METODE}

Metode sejarah digunakan dalam merekonstruksi orang-orang Arab di Manado pada tahun 1899 M. Aktivitas orang-orang Arab tergolong aktif dan masif masuk ke Nusantara sampai abad ke-19 M. Pengumpulan data menggunakan sumber literatur yang berikatan dengan tema yang disajikan dalam tulisan ini. Beberapa sumber yang membahas orang-orang Arab dipilah dan dipilih untuk memperoleh data rekonstruksi peristiwa yang berkaitan dengannya, baik berupa laporan pemerintah Belanda, dan buku-buku. Interpretasi singkat dari data yang diperoleh dengan diperkuat analisa-deskriptif untuk membangun sebuah deskripsi sejarah sebelum adanya penulisan atau historiografi. Dengan demikian, setidaknya kita dapat melihat kembali proses awal dari keberadaan orang Arab di Nusantara, khususnya di Manado, sebagai sebuah kesinambungan sejarah dan juga rekonstruksi aktivitas perdagangan maritim yang selama ini diketahui sebagai daerah penghasil rempah terbaik di dunia.

Penelitian ini menggunakan metode penelitan sejarah yang terdiri atas empat tahapan: heuristik, kritik sumber atau verifikasi, interpretasi, dan historiografi (Abdurrahman 2007:63, Kuntowijoyo 2005:90).

Tahapan pertama, heuristik, dilakukan dengan mengumpulkan berbagai macam sumber literatur, baik buku, laporan perjalanan, bahkan tulisan-tulisan lepas yang diperoleh dari beberapa perpustakaan, terutama dari Pepustakaan Universitas Islam Negeri (UIN) Sunan Kalijaga Yogyakarta, Perpustakaan Universitas Gadjah Mada (UGM) Yogyakarta, Arsip Nasional Republik Indonesia (ANRI), Perpustakaan Balai Pelestarian Nilai Budaya (BPNB) Sulawesi Utara, dan Arsip Sulawesi di Makassar. Di sisi lain, 
Handep Jurnal Sejarah dan Budaya Vol. 4, No. 1, Desember 2020, hlm. 61-86

penulis juga memanfaatkan beberapa website jurnal www.researchgate.net, www.garuda.ristekbin.go.id, dan aplikasi mendeley, serta menggunakan satu sumber dari surat kabar kolonial seperti Soerabaijasch-handeslblad.

Tahapan kedua adalah kritik sumber atau verifikasi. Dalam tahapan ini dilakukan seleksi data yang sesuai dengan topik penelitian. Untuk sumber utama, penulis melakukan seleksi terhadap beberapa arsip yang diterbitkan oleh pemerintah kolonial yang berhubungan dengan diaspora dan aktivitas niaga maritim para pedagang Arab di Semenanjung Laut Sulawesi, khususnya di Keresidenan Manado. Untuk data pendukung, penulis menggunakan buku-buku yang diterbitkan dan jurnal penelitian yang membahas situasi dan keadaan pada masa itu.

Tahapan ketiga, interpretasi, dilakukan setelah seleksi. Upaya yang dilakukan ialah melihat kembali korelasi dan hubungan antara sumber sejarah yang diperoleh dengan konteks peristiwa sejarah pada masa itu.

Tahap keempat adalah historiografi. Tahapan ini adalah tahapan penulisan karya sejarah sebagaimana yang tertuang dalam jurnal ilmiah ini.

Kajian ini merupakan pengembangan ide dari kerja lapangan penulis yang dilakukan pada tahun 2017 dengan judul "Arab-Gorontalo: Sebuah Sketsa Awal Masyarakat Arab di Gorontalo Abad XIX-XX M" dan juga tesis penulis yang dikerjakan pada tahun 2019 yang berjudul "Diaspora dan Perdagangan Maritim Komunitas Arab di Bandar Manado 1888-1900 M". Kedua wilayah dalam tulisan ini saling berkaitan di mana Gorontalo dan Manado menjadi kawasan penghubung dan penyuplai komoditas, terutama beras, kelapa, dan kopra, yang dijalankan oleh beberapa pedagang pengusaha Arab. Pengaruh pedagang etnis Arab baik di Gorontalo dan Manado mempercepat terjadinya proses diaspora di kawasan pesisir Semenanjung Laut Sulawesi, dan secara khusus mereka memilih Manado karena lebih dekat dengan Maluku, sedangkan yang lainnya menganggap Manado sebagai wilayah yang mampu memproduksi komoditas dengan harga yang terjangkau. Proses inilah yang menunjukkan bahwa terjadi relasi dan integrasi ekonomi maritim di kawasan timur Nusantara, khususnya Pulau Sulawesi.

\section{HASIL DAN BAHASAN}

Nusantara di masa lalu dikenal sebagai daerah yang majemuk dan menjunjung tinggi pluralisme. Pluralisasi terjadi dalam masa yang panjang dengan masuknya berbagai macam pendatang, terutama dari latar belakang keagamaan, hingga menghasilkan keragaman budaya. Di masa sekarang, keragaman tersebut kembali dipertanyakan melalui konflik identitas dan konflik keagamaan. Catatan tersebut kembali membuka pengalaman sejarah di masa lalu, terutama di kawasan Manado. Etnis Minahasa lebih 
banyak mendiami daratan wilayah Manado. Hal ini tidak lepas dari proses panjang sejarah dalam menyatukan sub-suku yang mendiami daratan Manado (Moelsbergen 1928:53). Meski demikian, daratan Manado tidak menganut sistem pemerintahan kerajaan, melainkan sistem pemerintahan yang terbuka. Prinsip pemerintahan yang dimaksudkan di sini mengacu pada penyatuan kelompokkelompok yang terpisah secara kultural, linguistik, menjadi 'satu' kesatuan identitas. Dalam catatan sejarah, Heeres dan Stapel (1934:173) menulis bahwa terdapat 23 walak yang ditunjuk oleh masyarakat etnis sebagai 'wakil' di daratan Minahasa, dan juga Manado, yang melakukan perjanjian dengan VOC pada tahun 1679. Dalam catatan lain menuliskan bahwa sikap egaliter yang dipraktikkan di Manado adalah sebuah sistem pemerintahan tradisional yang terkandung dalam makna kata "Minahasa". Minahasa adalah simbol suara rakyat dari penyatuan wilayah (Henley 1996:23, Supit 1988:141). Di masa kini, Manado menjadi ibu kota pemerintahan Sulawesi Utara yang mana di dalamnya merupakan sekumpulan etnis utama di Indonesia seperti Minahasa, Bolaang, Mongondow, Sangihe, dan Talaud.

Manado menjadi titik sentral dalam pergerakan sejarah di Minahasa, sebab kawasan tersebut merupakan pusat aktivitas, ekonomi dan pemerintahan. Wilayah Manado, dahulunya merupakan pusat pemerintahan yang dibentuk oleh pemerintah kolonial yang dikenal dengan nama Keresidenan Manado.

Dalam arus sejarah yang berkembang, Manado mengalami dinamika yang cukup masif. Kawasan ini tidak hanya dikenal sebagai bandar dan pelabuhan transit, namun sebagai melting pot bagi para pedagang dari berbagai etnis. Manado yang dikenal sebagai bandar niaga maritim, menarik para pedagang dari berbagi etnis dan identitas agama mengisi ruang tersebut. Lebih khusus bagi para pedagang Arab yang terlibat langsung dalam aktivitas distribusi, produksi, hingga konsumsi komoditas. Artinya, mereka juga memenuhi kebutuhan permintaan dan penawaran dalam aktivitas niaga maritim dalam jejaring rempah-rempah dari dan ke Maluku.

Pada periode abad ke-19, Manado lebih dikenal sebagai bandar niaga milik pemerintah kolonial yang ditunjuk sebagai pelabuhan perantara pada tahun 1848. Penunjukan ini tidak lepas dari wilayah Manado yang strategis sebagai pelabuhan penghubung, bahkan sebagai pelabuhan penyalur komoditas, terutama beras, kelapa, kopra, dan hasil laut. Usaha pemerintah kolonial atas bandar Manado berdampak positif terutama banyaknya pedagang yang datang mengunjungi Manado untuk sekedar berniaga atau mengumpulkan komoditas yang banyak dihasilkan di Manado. Salah satu pedagang yang terlibat aktif dalam kegiatan tersebut adalah para pedagang Arab yang rutin mengunjungi Manado dalam setiap 
Handep Jurnal Sejarah dan Budaya Vol. 4, No. 1, Desember 2020, hlm. 61-86

pelayarannya. Bahkan beberapa di antara pedagang Arab tersebut memilih untuk berdiaspora dan migrasi ke Manado karena alasan keuntungan ekonomi.

Namun usaha tersebut tidak dapat berjalan dengan baik meskipun memberikan keuntungan bagi para pedagang Arab yang ada di Manado. Beberapa kebijakan pemerintah kolonial dalam aspek ekonomi, politik, hingga sosial berdampak besar dalam kehidupan para pedagang etnis Arab yang ada di Manado. Pada bidang ekonomi, kebijakan zeebrief dan jaarpas memberikan kerugian secara ekonomi bagi para pedagang Arab apabila ingin berniaga di Manado. Pada bidang politik, mereka harus mengikuti kebijakan politik yang dikeluarkan oleh pemerintah kolonial yang ada di Manado. Sedangkan pada bidang sosial, klasifikasi kelas menjadi hal yang paling menonjol dalam kehidupan sosial para pedagang etnis Arab. Oleh karena itu, para pedagang etnis Arab yang terlibat dalam aktivitas niaga maritim dalam jejaring rempah-rempah di Manado memilih untuk tetap mengikuti kebijakan yang diterapkan oleh pemerintah kolonial agar dapat bertahan. Di samping itu pula, mereka juga menjalin relasi dengan pemerintah kolonial dalam urusan distribusi, dan produksi komoditas.

Usaha ini ternyata berdampak pada sisi yang lain bagi para pedagang etnis Arab di Manado. Mereka tidak banyak terlibat dalam persoalan politik di Manado, namun dalam urusan ekonomi dan kehidupan sosial mereka justru memberikan implikasi baik bagi pertumbuhan dan perkembangan Manado pada akhir abad ke-19 hingga awal abad ke-20. Untuk itu dalam kajian ini pembahasan difokuskan pada diaspora, migrasi, dan pembentukan identitas etnis Arab yang terjadi di Manado. Pembahasan ini menguraikan proses sejarah yang diawali dengan melihat kembali Manado pada periode abad ke-19 dalam jejaring niaga maritim dan jalur rempah-rempah, proses diaspora dan migrasi para pedagang Arab ke Manado, aktivitas niaga dan relasi yang terjadi, serta menunjukkan awal pembentukan identitas masyarakat Arab di Manado pada awal abad ke-20.

\section{Manado dan Pedagang Arab Menjelang Akhir Abad ke-19}

Lapian (2009) mengungkapkan Laut Sulawesi sebagai jalur penghubung antara Sulu-Maluku-Makassar dalam jalur utama perniagaan pada abad ke-16 M sampai abad ke-19 M. Posisi ini sebagai poros yang mampu mengumpulkan berbagai macam komoditas di kawasan pesisir Manado. Praktik niaga di Manado juga melibatkan para pedagang Arab dalam jejaring Philip Channel yang terhubung dengan bandar Singapura, Sulu, dan Maluku (Broschberg 2017: 385). Catatan ini diperkuat melalui aktivitas niaga yang terjadi di Manado. Laporan dari keputusan Gubernur Jenderal van der Capellen tertanggal 14 Juni 1824, No. 10 (Staatsblad 28a) menunjukkan 
bahwa Laut Sulawesi, terutama Manado, memiliki posisi penting bagi pemerintah kolonial. Salah satu bunyi kebijakan tersebut menempatkan Manado sebagai keresidenan yang dikenal dengan nama Residentie van Menado (Besluit No. 10; Staatblaad 28a/16 Juni 1824). Manado sebagai pusat pemerintahan, dan ekonomi yang kemudian pada tahun $1856 \mathrm{M}$ kebijakan tersebut diperbarui dan memosisikan Manado sebagai ibu kota keresidenan (Milone 1996:11). Akibatnya, pusat pemerintahan dan ekonomi berada di pesisir Manado, hingga Manado ditunjuk sebagai kota niaga. Beberapa komoditas utama seperti pala, cengkih, beras, kelapa, kopra, dan hasil laut juga mengintegrasikan orang-orang Arab di berbagai wilayah (Hamid 2015:190), termasuk Manado.

Sejak keputusan penunjukan Manado sebagai ibu kota keresidenan berlaku, wilayah Manado secara tidak langsung berada di bawah hegemoni kolonial. Keputusan ini memiliki tujuan di antaranya mengurangi peran para pelaku niaga di bandar Manado, termasuk peran para pedagang Arab. Namun hal tersebut tidak berjalan dengan baik, meski pemerintah kolonial menerapkan kebijakan jaarpas dan zeebrief dalam aktivitas distribusi dan suplai komoditas, terutama beras pada tahun 1847 (Surat Keputusan Gubernur Jenderal No. 32, 27 April 1847). Salah satu bukti pemberlakuan pajak tersebut tertuang dalam pengangkutan komoditas beras yang diatur dalam distribusi perdagangan, termasuk dalam dokumen pajak, dan dokumen distribusi komoditas yang merujuk pada jaarpas dan zeebrief (Sulistiyono 1997:212-213). Kalangan pedagang Arab pada saat itu dibebankan pajak berlayar dan berniaga. Akibatnya pada abad ke-19 mereka banyak bergantung pada syahbandar dan luitenant Arab yang menjabat di Keresidenan Manado pada masa itu.

Terbukanya Manado sebagai bandar niaga, kemudian berdampak pada ramainya jalur dan jejaring niaga, hingga terjadinya diaspora dan migrasi penduduk. Salah satu kelompok yang merasakan dampak dari keterbukaan Manado sebagai bandar niaga adalah para pedagang etnis Arab. Mereka terlibat secara rutin berkunjung ke Manado untuk membeli komoditas rempah-rempah. Kedatangan mereka tidak lepas dari jalur niaga yang mereka lalui seperti Gorontalo dan Teluk Tomini (Hasanuddin 2014). Bahkan beberapa pedagang di antara mereka juga datang melalui Ternate dan Kema (Azis 2017: 49). Manado yang pada saat itu telah menjadi wilayah taklukkan pemerintah kolonial dan ditunjuk sebagai pusat pemerintahan administratif di Semenanjung utara Laut Sulawesi (Ulaen 2018:38). Keuntungan bagi Manado, tidak hanya sebagai pusat pemerintahan, namun juga sebagai pusat perekonomian di kawasan Laut Sulawesi. Menariknya, beberapa pedagang, termasuk Arab, memanfaatkan posisi Manado untuk 
Handep Jurnal Sejarah dan Budaya

Vol. 4, No. 1, Desember 2020, hlm. 61-86

memperoleh keuntungan melalui aktivitas niaga maritim.

Catatan keberadaan orang Timur Asing dari tahun 1568-1930, khususnya Arab dan Cina, secara keseluruhan mencapai 25.000 jiwa (Henley 2005:168-171). Mereka kebanyakan pedagang yang membawa kapal dengan tonase sekitar 10 ton. Beberapa di antara mereka juga menjadi perantara, dan pemilik modal (Henley 2005:87). Mereka datang melalui jalur niaga hingga tiba di pesisir Manado. Mereka juga datang membawa komoditas, seperti kain, yang ditukar dengan beras atau kelapa. Mereka tidak hanya mengunjungi dan mengumpulkan komoditas di Manado, namun juga membeli komoditas lainnya di kawasan bandar niaga internasional (Vickers 2013:20).

Ketika para pedagang Arab tiba di Manado, mereka membeli komoditas beras, dan juga menjalin hubungan niaga dengan penduduk pribumi. Pada awalnya hubungan keduanya adalah pembeli dan penjual, namun lambat laun mereka menjalin relasi intensif hingga menjadi partner niaga. Melalui hal tersebut para pedagang Arab membangun sebuah kekuatan ekonomi di Manado yang tidak hanya terlibat dalam hubungan pertukaran dan jual beli komoditas, namun juga perlahanlahan melakukan diaspora dan migrasi.

Keberadaan mereka di Manado berimplikasi pada dua hal yakni aktivitas ekonomi, dan aktivitas sosial. Para pedagang Arab memperoleh ruang di Manado tidak dengan memanfaatkan pendekatan keagamaan, namun dengan menggunakan pendekatan ekonomi. Tercatat pada akhir abad ke-19. Mereka mampu memanfaatkan ruang niaga untuk membangun sebuah kawasan permukiman sederhana di kawasan pesisir pantai Manado. Bahkan lambat laun mereka menjadi penduduk urban di Manado yang mampu berbaur dengan penduduk pribumi dan pendatang lainnya melalui praktik niaga yang dijalankannya.

Meski demikian, mereka mengalami perubahan pola dan alur niaga. Ruang bagi mereka, dalam arti politis, untuk berniaga dipersempit, sedangkan komoditas yang mereka harus distribusikan ke Manado terbatas dengan alasan untuk memenuhi kebutuhan rempah-rempah di Manado, dan juga menutupi kerugian akibat utang kolonial (Vlekke 2016:273). Pada praktiknya, kebijakan ini berhasil diterapkan di Manado, sehingga para pedagang Arab hanya diberikan kebebasan membawa kapal dengan tonase sekitar 200-600 ton dalam sekali perjalanannya. Artinya, kapal yang mereka gunakan untuk mengangkut komoditas tidak bisa melebihi kapal uap milik pemerintah kolonial. Pun dengan persoalan pembayaran pajak pelayaran yang ditetapkan oleh pemerintah kolonial yang mencapai sekitar $f 40$ dalam setahun.

Adapun kebijakan yang berlaku tersebut tidak berdampak signifikan untuk para pedagang Arab. Beban pajak yang mereka bayarkan kepada pemerintah kolonial setiap tahunnya 
yang berkisar $20-40 \%$ dari pendapatan tidak memengaruhi aktivitas niaga mereka di Manado. Mereka tetap membeli dan menyuplai komoditas di Manado, terutama beberapa komoditas terutama beras dan kopi yang dibawa ke Sumatra, Jawa, hingga Singapura (Suwondo 1977/1978:77). Di sisi lain, persoalan dan intrik agama menjadi penghalang utama antara pedagang Arab dan Belanda untuk menemui kata sepakat. Akibatnya, mereka terpaksa memosisikan dirinya sebagai perantara perniagaan di Manado (Azis 2019:102). Meskipun demikian, para pedagang Arab terlihat memiliki peran berbeda ketika berada di Manado. Mereka tidak banyak terlibat dalam proses penyebaran dan intrik agama, sehingga mereka mampu menjaga posisinya sebagai pelaku niaga.

Diangkatnya seorang controleur, dan walak ${ }^{l}$ yang bertugas mengatur jalannya pemerintahan dan pengumpulan pajak adalah bukti Manado mampu menjadi pusat ekonomi di kawasan Laut Sulawesi (ANRI 1971:45). Sedangkan bagi orang-orang Arab, penunjukan luitenant Arab menegaskan posisi mereka di Manado sebagai salah satu etnis yang dibutuhkan bagi pemerintah kolonial pada akhir abad ke-19. Lancarnya aktivitas mereka

1 Controleur atau asisten residen bertugas sebagai pejabat pemerintah Hindia Belanda yang bertugas mengawasi aktivitas politik dan ekonomi para penduduk dan pendatang. Dan walak bertugas sebagai pengatur jalannya pemerintahan di wilayah-wilayah kecil yang ada di bawah pengawasan controleur. di Manado tidak membuat pedagang Arab berhenti menjalin relasi dengan penduduk pribumi, dan juga pemerintah kolonial, meskipun harus membayar pajak yang cukup besar. Salah satu bukti bahwa mereka memiliki kontribusi bagi Manado adalah dengan relasi komunal yang terjalin, kemudian pembangunan infrastruktur dalam memudahkan akomodasi dan perpindahan komoditas di daratan, hingga terbentuknya pasar niaga yang menjadi pusat penjualan komoditas di pesisir Manado (Graafland 1991:15).

\section{Diaspora, Migrasi, dan Jejaring Niaga Maritim: Kasus Arab di Manado Akhir Abad ke-19}

Posisi Manado yang masuk dalam bagian heartsea di kawasan Timur menarik perhatian pedagang Arab. Catatan terdahulu memperkuat kondisi Manado yang mana kawasan ini mampu memproduksi beras dengan nilai jual tinggi (Moelsbergen 1928:8; Wigboldus 1987:67; Graafland 1989:2). Selain itu, mereka juga menjual karet, hasil hutan, dan hasil laut kepada para pedagang Eropa dan Cina melalui jaringan yang sudah dibangun pada masa lalu (Kaptein 2017).

Diaspora Arab di Manado diawali dari poros niaga rempah-rempah yang mana Manado termasuk dalam kawasan entrepot dan melting point perniagaan. Mereka berdiaspora karena ketertarikan dan keterikatan terhadap komoditas beras, kopi, dan rempahrempah. Mereka menjalin relasi dengan 
Handep Jurnal Sejarah dan Budaya

Vol. 4, No. 1, Desember 2020, hlm. 61-86

penduduk dan penguasa lokal untuk jalur distribusi komoditas (Taulu 1977:1-3). Selain sebagai pedagang, mereka juga memiliki keahlian seperti pertukangan. Mereka datang bersamaan dengan para pedagang dari Ternate dan Maluku dan juga orang Cina serta Bugis-Makassar (Taulu 1977:3). Dampak hegemoni politik antara Belanda-Makassar-Ambon juga semakin mempercepat proses perpindahan mereka ke kawasan pesisir, termasuk di Manado.

Proses diaspora Arab di Manado mengalami peningkatan menjelang tahun 1900. Mereka menjadikan Manado sebagai tujuan karena wilayah tersebut cukup aman dan menguntungkan baginya. Terbukti ketika seorang pedagang Arab yang singgah ke Manado untuk membeli komoditas di kawasan pesisir Manado, setelah dari Maluku. Mereka tertarik dengan produksi komoditas kopi, dan juga hasil bumi yang mampu dipasarkan di Singapura dan kawasan lainnya (Taulu 1977:8).

Mereka datang menggunakan alat transportasi tradisional. Kapal-kapal layar tradisional seperti palari, padewakang, kora-kora, sapit, lipa, dan vinta terlihat lalu lalang di bandar Manado sampai akhir abad ke-19 M.

Haji Oemar seorang pedagang yang terlibat dalam jejaring perdagangan internasional menggunakan kapal padewakang. Terbukanya perusahaan dagang semakin membuka ruang diaspora melalui perusahaan Firma Reiss \& Co (ANRI, No. 31, Bundel 53,
1874 dan 1877), dari pembukaan perusahaan tersebut berdampak pada keuntungan pedagang Arab di Manado tahun 1899 yang mencapai keuntungan $f$ 17,5 setiap tonnya (Asba 2007:151).

Menariknya, seorang pedagang Arab mampu menjadi navigator yang berlayar di kawasan Laut Sulawesi dengan membawa beberapa komoditas, terutama budak (Inventaris Arsip Gorontalo1810-1865). Bahkan sebuah perusahaan milik Syaikh Sa'id Abdallah bin Adilla ini mendapatkan izin belayar dan berniaga dari pemerintah kolonial untuk beroperasi di antara Maluku, Manado, dan Singapura. Perusahaan tersebut menggunakan kapal uap untuk mengangkut komoditas cengkih dari Maluku yang menyinggahi Manado dan melanjutkannya ke Singapura (Clarence-Smith, 1998: 40).

Pengangkatan seorang penasihat dari kalangan Arab pada tahun 1891, Sayyid Utsman bin Yahya, memperkuat posisi etnis Arab di Nusantara (Steenbrink 2017:137-138). Mereka bergerak lebih leluasa untuk berdagang dan berniaga, meski di satu sisi terjadi penekanan dalam persoalan dan intrik agama. Pengangkatan tersebut bertujuan untuk menghindari terjadinya pemberontakan dan perlawanan dari kalangan etnis Arab dengan alasan kedekatan ideologi agama dengan penduduk pribumi.

Di sisi lain, pandangan stereotipe terhadap orang-orang Arab justru berdampak pada kondisi cepatnya proses diaspora dan migrasi para 
pedagang Arab di Nusantara, termasuk di Manado. Van den Berg (2010:152) mencatatkan bahwa selain proses niaga, faktor pendidikan juga memengaruhi proses diaspora dan migrasi orangorang Arab di berbagai kawasan di Nusantara. Beberapa di antara mereka ikut berniaga dan juga menyiarkan ajaran Islam pada penduduk pribumi. Namun kondisi ini berbeda dengan yang terjadi di Manado. Mereka justru banyak terlibat dalam poros niaga, dan tidak terlibat langsung dalam aktivitas politik.

Pengasingan seorang tokoh dari Palembang, Sayyid Abdullah Assegaf, pada tahun 1881 menjadi catatan tersendiri dalam keberadaan orang Arab di Manado. Tokoh tersebut diasingkan karena perlawanan terhadap pemerintah kolonial, namun di Manado dia dikenal sebagai seorang pengajar yang menyiarkan Islam, terutama di distrik Tondano (Bizawie 2016:480).

Dampak dari pengasingan tersebut memperkuat posisi orang-orang Arab. Beberapa pedagang Arab memperoleh ruang niaga yang terbuka dengan penduduk pribumi di Manado dan juga Minahasa. Bahkan mereka lebih banyak dikenal berprofesi sebagai pedagang yang juga menyiarkan Islam (Babcock1989:284). Bukti lain dari keberadaan mereka di Manado ialah berdirinya Kampung Arab di pesisir Manado. Konteks ruang yang mengindikasikan bahwa kekuatan ekonomi mampu menjadi salah satu faktor kesuksesan diaspora dan migrasi dalam poros jejaring maritim.
Kampung Arab berbeda dengan Kampung Islam, dalam konteks politik yang dibangun oleh pemerintah kolonial di Manado. Mereka dipisahkan untuk memudahkan kontrol pemerintah atas aktivitas yang dilakukan para pedagang dan pelaku niaga di kawasan pesisir Manado (Parengkuan 1983:2930). Pada sekitar tahun 1890 menjadi titik balik masyarakat di sekitar pelabuhan Manado, termasuk Arab. Pembangunan kota kolonial di Manado yang berciri khas dengan benteng sebagai pusatnya menempatkan orangorang asing, baik Arab dan Cina, berada di sisi timur benteng. Sedangkan untuk penduduk pribumi berada di sebelah selatan yang tidak melewati dengan batas benteng milik Belanda. Etnik Arab lebih dekat dengan masyarakat Muslim dari daerah lain di Nusantara. Kedekatan tata kota ini untuk memudahkan pemerintah Belanda dalam mengontrol para pendatang. Bagi umat Islam, hal itu adalah sebuah keuntungan karena jalan setapak yang berdekatan, bangunan ibadah pun tidak jauh dari sekitar permukiman tersebut. Seperti Kampung Arab yang berdekatan dengan Kampung Islam di Manado di mana tata letaknya berdampingan dan juga dipusatkan pada satu tempat ibadah, masjid, yang berada di sisi pantai waktu itu.

\section{Etnis Arab Manado Akhir Abad ke-19 M: Komoditas dan Lahan Menjelang tahun 1899 M eksploitasi lahan semakin meningkat. Komoditas yang diproduksi di Manado juga}


Handep Jurnal Sejarah dan Budaya

Vol. 4, No. 1, Desember 2020, hlm. 61-86

semakin banyak, terutama kelapa dan kopra. Di Manado terdapat dua jenis lahan yang dimaksimalkan yakni pasini dan kalakeran. Pasini dan kalakeran berbeda fungsi dalam produksi komoditas beras, kopi, dan kelapa pada periode tahun $1890 \mathrm{M}$ (Ulaen 2018:40). Tanah pasini merupakan lahan garapan yang diolah sendiri oleh pemilik lahan, sedangkan untuk tanah kalakeran lahan yang dioleh oleh komunal dan milik pemerintah dan biasanya diawasi oleh seorang kepala walak atau wijkmeester (Azis 2019:80). Pengolahan lahan pada akhir abad ke-19 dan awal abad ke-20 berorientasi pada sawah dan ladang yang menghasilkan komoditas beras (Henley 2005:526).

Pengolahan tersebut berdampak pada hasil produksi di Manado, yang juga berdampak pada peningkatan aktivitas ekonominya. Tidak hanya beras, kopi juga kembali diperdagangkan meski mengalami penolakan oleh penduduk pribumi karena sistem kerja dan suplai komoditas yang dimonopoli oleh Belanda. Meskipun demikian, Schouten (1998:58) melaporkan bahwa terjadi penyelundupan kopi yang dilakukan oleh penduduk pribumi untuk memenuhi kebutuhan pedagang Arab. Bagi pedagang Arab keuntungan yang diperoleh dari menjual komoditas kopi mencapai $f \quad 25$ setiap pikulnya (Soerabaijasch-Handelsblad 8 september 1893).

Bahkan beberapa diantaranya juga tidak hanya berusaha mengumpulkan komoditas, namun juga meningkatkan usaha ekonominya dengan menjadi pemilik lahan. Pada kasus kawasan Keresidenan Manado, pedagang Arab bernama al-Hasni menjadi pemilik lahan kelapa yang diperoleh dari memberikan pinjaman modal kepada penduduk pribumi. Bahkan seorang pedagang Arab bernama Syarif Ali menjadi pedagang keliling yang menjual beberapa kebutuhan seharihari hingga membuka toko di sekitar pesisir Manado. Ada juga yang menjadi pendidik atau pemuka agama ketika ajaran Islam semakin kuat di Gorontalo (Azis 2019:66).

Para pedagang Arab juga menjadi pemberi modal di Manado untuk mengolah lahan, terutama pada lahan perkebunan kelapa. Beberapa di antara pedagang Arab, seperti al-Hasni, Baadillah, dan al-Husni, dikenal sebagai orang kaya yang berniaga di Manado. Ketiganya sering memberikan pinjaman kepada penduduk pribumi untuk mengolah lahan perkebunan kelapa dengan jaminan lahan tersebut. Apabila utang tersebut tidak dapat dilunasi dan dibayarkan, maka lahan tersebut otomatis menjadi milik pemberi modal atau hutang. Hal ini diperkuat melalui status kepemilikan lahan dan tanah yang berpindah tangan ke beberapa pemilik modal, terutama dari kalangan etnis Arab. Namun karena Manado dan Minahasa menjadi daerah yang diatur langsung oleh pemerintah kolonial. Akibatnya, beberapa kepemilikan lahan beralih 
status, sehingga status tanah legal milik pribumi dan sekelompok burgers $(\text { borgo })^{2}$ yang dieksploitasi untuk kepentingan pemerintah kolonial (Wiersma 1880:820-823).

Aktivitas dan pola niaga di Manado perlahan berubah. Bagi kalangan Arab yang beraktivitas niaga di Manado, mereka membeli komoditas kepada penduduk pribumi dalam jumlah kecil. Bahkan ada juga yang yang menyelundupkan kopi karena harga mahal yang diberikan pemerintah kolonial. Hal ini dilakukan untuk menutupi kerugian akibat menurunnya produksi komoditas kopi (Schouten 1998:63).

Beberapa pedagang Arab yang sudah menetap di Manado mengalami pembatasan aktivitas niaga. Mereka beralih menjadi pemilik lahan dengan keuntungan yang diperoleh dari distribusi dan suplai komoditas ke beberapa kawasan lain. Mekipun demikian, mereka tetap terbebani oleh pajak besar yang harus disetorkan kepada pemerintah kolonial di Manado. Pembatasan ini berlaku dalam peraturan pembatasan kepemilikan lahan, distribusi, dan suplai komoditas, hingga pengangkutan harus melalui persetujuan pemerintah kolonial, sehingga hal tersebut memberatkan bagi pedagang Arab yang berniaga di Manado (Crab 1862:53).

2 Kelompok burger atau borgo merupakan istilah yang digunakan oleh pemerintah kolonial untuk menyebut penduduk campuran dari berbagai etnis.
Di sisi lain, hubungan mereka dengan penduduk pribumi berjalan lancar, meskipun harga komoditas mengalami peningkatan. Suplai komoditas secara rutin dilakukan, dan di sisi lain mereka memerlukan penyesuaian harga di pasar lokal. Akibatnya beberapa di antara mereka mengekspor komoditas dalam jumlah kecil ke Jawa atau ke Ternate melalui pelabuhan Manado (Suwondo 1977/ 1978:78).

Di saat pola niaga pedagang Arab mengalami pembatasan yang juga diikuti dengan kerugian, maka mereka lambat laun mencari alternatif untuk mempertahankan keberadaannya. Pola dagang dengan cara berkeliling dilakukan dengan membawa beberapa kebutuhan sehari-hari, mereka juga perlahan mengalihkan perhatiannya pada aspek pendidikan dan sosial. Pengangkatan seorang luitenant Arab di Manado berperan penting dalam mempertahankan keberadaan orang Arab di Manado. Luitenant Arab yang ditunjuk, berperan sebagai pengontrol dalam sistem politik, dan juga perantara niaga bagi pemerintah kolonial. Posisi tersebut juga menjadi kekuatan sosial bagi orang-orang Arab di Manado. Selain sebagai pedagang, beberapa di antara mereka juga berprofesi sebagai guru dan imam masjid di kalangan masyarakat Arab dan muslim Manado. 
Handep Jurnal Sejarah dan Budaya

Vol. 4, No. 1, Desember 2020, hlm. 61-86

4. Orang Arab Manado: Kontinuitas, Mobilitas, dan Identitas Awal Abad XX

Dua tokoh Arab yang tercatat aktif pada awal abad ke-20 di Manado adalah Amr al Taijb dan Sayid Akhmad bin Alawi Alaydrus yang menetap di Kampung Islam, pesisir Manado (Algemeen Verslag 1868). Mereka tercatat sebagai luitenant Arab yang dipilih oleh pemerintah kolonial. Tujuan utama penunjukan tersebut adalah untuk mengakomodasi aktivitas orang-orang Arab dan masyarakat Muslim di Manado.

Berdirinya Stad Vlaardingen ${ }^{3}$, perkampungan kolonial, di pesisir Manado memperkuat posisi pedagang Arab. Orang-orang Arab dikelompokkan menjadi satu bagian dengan penduduk Muslim lainnya. Diangkatnya kepala, kopitein atau luitenant, yang kemudian berubah jabatan sebagai wijkmeesteer pada abad ke-20 M menjadi bukti peran orang Arab di Manado (Regerings Almanak 1915; Adam 1975:26).

Posisi orang Arab di Manado mengalami perkembangan setelah pendidikan Islam mulai diperkenalkan. Orang-orang Arab di Manado banyak belajar dan menuntut ilmu melalui

\footnotetext{
3 Stad Vlaardingen adalah tempat tinggal yang dikhususkan untuk orang-orang Belanda dan keturunannya. Sederhananya, Stad Vlaardingen merupakan kota klolonial yang dibangun pemerintah kolonial untuk mudah mengontrol penduduk pribumi dan pendatang yang beraktivitas di sekitar benteng kolonial. Ciri khas dari Stad Vlaardingen adalah benteng yang menjadi pusat pemerintahan.
}

lembaga al-Khairat di Palu. Mereka banyak berguru kepada Sayyid Idrus bin Salim Aljufri pada awal tahun 1900. Dampaknya semakin terlihat ketika lembaga Al-Khairat berdiri di Manado pada tahun 1947 dengan salah satu tujuan utamanya memperkuat relasi orang-orang Arab di Sulawesi, terutama di Manado (Rasyid et al. 2018).

Struktur masyarakat yang bertumbuh dan berkembang di Manado semakin terbuka bersamaan dengan munculnya permukiman di kawasan pesisir Manado. Para pedagang Arab merasakan dampak panjang dari proses perpindahan komoditas. Mereka yang rutin menyuplai dan membeli komoditas mampu menarik perhatian para penduduk pribumi (Amir dan Utomo 2016:108). Bagi mereka, Manado mengalami kemajuan sebagai sentra niaga pada abad ke-20. Bagi pedagang Arab, mereka tidak hanya sekedar memenuhi konsumsi dan distribusi ekonomi di sekitar pesisir Manado, namun juga memasok ke kawasan pedalaman di daratan Manado dan Minahasa. Munculnya toko-toko milik pedagang Arab dan Cina yang berjejer di sekitar benteng Manado menjadi pusat niaga di Manado,

Aktivitas ini meningkatkan frekuensi kerja sama antara pedagang Arab dan penduduk pribumi untuk menyediakan komoditas. Perputaran ekonomi yang lancar di Manado berdampak secara paralel. Para pedagang Arab bertahan di Manado melalui dinamika ekonomi yang relatif 
aktif melalui suplai komoditas yang lancar.

Di abad ke-20 aspek sosialekonomi bagi pedagang Arab tetap terjalin hubungan dengan penduduk pribumi di Manado dan Minahasa. Hal ini dibuktikan oleh Graafland di mana orang-orang Arab dan Cina hidup berdampingan di Manado (Graafland 1989:12-13), dan diperkuat melalui permukiman yang tumbuh di Manado hingga abad ke-20. Relasi perekonomian membuat mereka semakin menguat dengan berdirinya sebanyak 47 titik pasar pada tahun 1901 dengan Manado sebagai pusat niaga, serta pedagang Arab sebagai penyuplai komoditas (Tumbel 1996:2).

Koloni dan pembentukan identitas komunal orang Arab seringkali berdasarkan pada aktivitas ekonominya. Beberapa saudagar Arab menjalin hubungan baik dengan para pedagang lokal, Eropa dan Cina, namun ada juga yang terlibat konflik politik dengan pemerintah kolonial, sehingga beberapa orang Arab mendapatkan perlakukan "khusus". Seperti Sayyid Muhammad bin Abu Bakar Aidid yang dengan sukarela menerima pengaruh politik Belanda dengan memahami posisi pemerintah Gubernur Jenderal Belanda yang berada di Buitenzorg, Bogor. Sayid Syaikh bin Ahmad Bafaqih yang bekerja sama dengan Sultan Sumenep, Sultan Paku Ningrat, dalam memajukan kebudayaan dan tradisi orang Arab di Sumenep (Berg 2010:108).
Beberapa orang Arab dikenal sebagai pedagang dan pengusaha. Sayyid Abd Al-Rahman bin Syaikh alHasni merupakan saudagar yang berpengaruh di kawasan Laut Sulawesi. Dia tercatat sebagai salah seorang yang memiliki saham pada perusahaan asal Jepang, Celebes Development Company (Cedeco). Pada tahun berikutnya, dia berhasil mendirikan Motor Kustvaart Maatshappij, Mokumij, yang memiliki saham sebesar 45\% (Purba 2018:45). Di sisi lain, seorang saudagar, bernama al-Habsyi merupakan aktor kesuksesan orang Arab di kawasan Laut Sulawesi dan Maluku yang rutin menyuplai dan membeli komoditas dari Manado.

Puncaknya aktivitas ekonomi mampu mendorong posisi orang Arab di Manado pada abad ke-20 mereka tidak hanya sebagai pelaku niaga namun juga bertahan di Manado dengan status quo sebagai pendidik dan pengajar agama Islam. Poros ekonomi yang mereka bentuk tidak lagi terlihat dengan jelas, sehingga mereka dikenal sebagai pedagang yang juga memiliki profesi lain seperti guru, penghulu, dan kadi (Endt 1936:11; Makkelo 2010:99). Sebagaimana yang dilaporkan oleh Alting menyebutkan guru agama, termasuk orang-orang Arab, di Minahasa dan Manado harus mendapatkan persetujuan dari Belanda seperti Lawangirung, Banjer, dan Sonder (Alting 1902:146-149). 
Handep Jurnal Sejarah dan Budaya Vol. 4, No. 1, Desember 2020, hlm. 61-86

Kondisi tersebut memengaruhi praktik kebudayaan masyarakat Arab. Representasi orang Arab di Manado mengikuti konteks sosial masyarakat. Van Aken menyebutnya sebagai anomali orang Arab yang mampu bertahan dalam jumlah minoritas. Mereka menyatu dengan penduduk pribumi yang menunjukkan cinta, kasih, damai, dan ramah antarpenduduk. Walau demikian, beberapa orang masih dianggap sebagai kelompok Islam yang mampu memberikan ancaman dan rawan terhadap pemberontakan $(\mathrm{MvO}, \mathrm{A}$. $\mathrm{Ph}$. Van Aken, 1932, Koleksi Nan No. 306).

Pada kehidupan pemerintahan orang Arab, yang dikelompokkan sebagai Timur Asing mendapatkan satu posisi penting pada Dewan Minahasa sebagaimana yang tertuang dalam Staatsblaad 1919 No. 64 jo, 1920 No. 343. ${ }^{4}$ Dari sini kalangan orang-orang Arab dapat menyalurkan aspirasinya mengenai kondisi mereka, meskipun pada praktiknya lebih banyak bersifat kebijakan struktural semata. Mereka ditempatkan pada sisi timur Benteng Amsterdam yang dpimpin oleh seorang luitenant, Sayyid Habib bin Abdullah al-Hasni dan mendapatkan ruang bebas dalam praktek kehidupannya. Tokoh ini kepala desa dari kalangan Arab di Manado sebelum status Keresidenan

\footnotetext{
4 Hal ini berisi mengenai anggota Dewan Minahasa yang bertugas di Keresidenan Manado. Sebanyak 41 orang anggota dengan rincian diisi 36 dari kalangan pribumi dan 1 dari Timur Asing, dan 4 orang Eropa. MvO, van Aken Mei 1932 No. 306.
}

Manado diubah menjadi gementee di tahun 1919 ( $M v O$, A. Ph. Van Aken, 1932, Koleksi Nan No. 306).

Dunia pendidikan orang Arab di Manado berpengaruh pada perkembangan lembaga pendidikan Al-Khairat di Palu. Mereka memilih Al-Khairat sebab model pendidikan yang ideal bagi mereka. Tradisi keislaman dipertahankan dengan baik, dan juga menjadi rujukan bagi orang-orang Arab di Manado dalam dunia pendidikan Islam di daratan Sulawesi (Jumat 2012:104).

Persebaran orang Asia Timur, termasuk Cina dan Arab di Manado, melalui catatan Volkstelling 1930 hampir mencapai $40 \%$ dari jumlah penduduk keseluruhan dalam Residensi Manado. Artinya, hampir seluruh kawasan pesisir dalam jalur niaga di kawasan Laut Sulawesi didiami oleh para pedagang. Secara keseluruhan, pendudukan orang Arab dan keturunannya di kawasan ini mampu meningkatkan kuantitas penduduk sekitar 3,5\% antara tahun 1885-1930 M (Gunawan 2013).

\section{SIMPULAN}

Proses sejarah orang-orang Arab masuk ke Nusantara dapat dipilah menjadi tiga unsur yakni, ekonomi, sosial, dan keagamaan. Keberadaan mereka diawali dari proses diaspora ekonomi untuk memperoleh komoditas rempahrempah. Di sisi lain, mereka menjalin relasi untuk kepentingan pendapatan dalam transaksi komoditas niaga. Ekspor, impor, dan suplai komoditas yang rutin membuat mereka melakukan 
perjalanan ke Nusantara, tujuan utamanya adalah Maluku. Proses diaspora sederhana karena kondisi ekonomi dan mencari wilayah subur untuk memenuhi kebutuhan mereka. Secara spesifik, mereka berdiaspora untuk kepentingan ekonomi, namun dampaknya ber-langsung pada pembentukan koloni-koloni kecil di kawasan strategis.

Di Manado, para pedagang etnis Arab menjadi pembeli dan penyuplai komoditas niaga melalui jejaring dan rute niaga maritim. Para pedagang dari etnis Arab membuka ruang niaga dengan menjalin relasi dengan penduduk pribumi. Selain aktif dalam jejaring niaga maritim, etnis Arab mampu menjadi penguasa beberapa lahan milik pribumi, terutama lahan perkebunan kelapa dan komoditas kopra.

Poros dan aktivitas niaga maritim berdampak pada proses diaspora dan migrasi serta pembentukan identitas agama di Manado pada awal abad ke-20. Para pedagang Arab berdiaspora dan migrasi ke Manado melalui aktivitas ekonomi melalui yang telah terjalin antara para pedagang etnis Arab dan penduduk lokal. Pembukaan ruang meningkatkan intensitas hubungan orang Arab dengan kelompok lainnya. Kenyataan sejarah membawa keseimbangan dalam relasi sosial di Manado. Peran orang-orang Arab di Manado tidak hanya seputar niaga, namun pada abad ke-20 juga berkontribusi pada kondisi sosial dan pendidikan bagi masyarakat Manado.
Orang Arab di Manado membangun identitas keagamaan dengan cara berbaur dengan penduduk pribumi. Mereka bersosialisasi dengan para penduduk melalui permukiman yang dibangun dan aktivitas niaga yang berkembang di sekitar pesisir Manado. Dalam konteks diaspora dan migrasi orang Arab, relasi harmonis yang terjadi di Manado mengantarkan mereka sebagai kelompok yang diterima di tengah-tengah Manado. Identitas keagamaan yang melekat pada orang Arab di Manado tidak menjadi penghalang bagi mereka untuk tetap bertahan. Tokoh-tokoh Arab berperan secara sosial untuk memperkuat posisi mereka di Manado. Pada abad ke-20 pengaruh identitas agama tidak banyak berpengaruh di Manado, sehingga mereka mampu menjaga kondisi keharmonisan antar-etnis di Manado.

\section{DAFTAR SUMBER}

Abdurahman, Dudung. 2007. Metodologi Penelitian Sejarah. Yogyakarta: Ar-Ruzz Media.

Adam, L. 1975. Sistem Pemerintahan di Minahasa. Jakarta: Bhatara.

Alting, J. H. Carpentier. 1902. Regeling van het Privaatrecht voor de Inlandsche Bevolking in de Minahassa-districten der Residentie Menado, edisi 1. Batavia: Landsdrukkerij.

Anonim. 1893. "Judul Artikel." Soerabaijasch Handelsblaad, 8 September. 
Handep Jurnal Sejarah dan Budaya Vol. 4, No. 1, Desember 2020, hlm. 61-86

Amir, Amrullah dan Bambang Budi Utomo. 2016. Aspek-aspek Perkembangan Peradaban Islam di Kawasan Indonesia Timur: Luwu dan Maluku. Jakarta: Direktorat Sejarah, Kemdikbud.

ANRI. Inventaris Arsip Residensi Menado 1677-1914 No. 56, Algemeene Verslag 1868.

ANRI, Inventaris Arsip Gorontalo 1810-1865 No. 6, Algemeen Verslag 1828-1829.

ANRI. 1971. Laporan Politik tahun 1837. Jakarta: ANRI.

ANRI. 1932. Memorie van Overgave $(M v O)$ A. Ph. Van Aken No. 306.

Arsip Nasional Republik Indonesia (ANRI). Inventaris Arsip Residensi Menado 1677-1914 No. 53, Algemeene Verslag 1874-1879.

Asba, A. Rasyid. 2007. Kopra Makassar Perebutan Pusat dan Daerah: Kajian Sejarah Ekonomi Politik Regional di Indonesia. Jakarta: Yayasan Obor Indonesia.

Azis, Muhammad Nur Ichsan. 2017a. Pelabuhan Kema dan Jaringan Muslim Nusantara Abad XX. Yogyakarta: Amara Books. . 2017b. "Arab-Gorontalo: Ruang Perjumpaan Masyarakat Arab di Nusantara Abad XX." Prosiding pada Seminar Merajut Kebhinekaan, Membangun Indonesia: Perspektif Sejarah dan
Budaya. Yogyakarta. BPNB D. I. Yogyakarta. 2019. Diaspora dan Perdagangan Maritim Komunitas Arab di Bandar Manado (18881900 M). Tesis, Fakultas Adab, Universitas Islam Negeri (UIN) Sunan Kalijaga.

Azra, Azyumardi. 2013. Jaringan Ulama Timur Tengah dan Kepulauan Nusantara Abad XVII dan XVIII. Bandung: Mizan.

Babcock, Tim. G. 1989. Kampung Jawa Tondano: Religion and Cultural Identity. Yogyakarta: Gadjah Mada University Press.

Bizawie, Zainul Milal. 2016. Masterpiece Islam Nusantara: Sanad Jejaring Ulama-Santri, 1830-1945. Tangerang: Pustaka Compass.

Burhanudin, J. 2014. "Diaspora Hadrami di Nusantara." Studia Islamika 6 (1): hlm. 181-201.

Borchberg, Peter. 2017. "Singapore and its Strait." Indonesia and the Malay World. 45 (133): hlm. 373-399.

Cabaton, Antoine. 2015. Jawa, Sumatera \& Kepulauan Lain di Hindia Belanda. Yogyakarta: Ombak.

Cohen, Robert., 2008. Global Diaspora: An Introduction, Second Edition. New York: Routledge. 
Clarence-Smith, William Gervase. 1998. "The Economic Role of the Arab Community in Maluku, 18161940." Indonesia and the Malay World. 36 (74): hlm. 32-47.

Ember, Melvin, Carol R. Ember, dan Ian Skoggard (ed.). 2005. Encyclopedia of Diasopora: Immigrant Refugee Cultures Around the World, vol. I. USA: Springer Science and Busines Media, Inc.

Freitag, U. 2009. "Chapter One. Reflections on the Longevity of The Hadhrami Diaspora In The Indian Ocean." Hlm. 17-32. In The Hadhrami Diaspora in Southeast Asia. BRILL. https://doi.org/ 10.1163/ej.9789004172319.i300.12

Graafland, N. 1991. Minahasa: Negeri, Rakyat, dan Budayanya. Terj. Lucy R. Montolalu. Jakarta: Pustaka Utama Grafiti.

Gunawan, Hendri. 2013. Yok Tjae \& Chung Hwa: Menelusuri Jejak Komunitas Tionghoa di Manado. Yogyakarta: Kanisius.

Hamid, Abdurrahman. 2015. Sejarah Maritim Indonesia. Yogyakarta: Ombak.

Hasanuddin. 2014. Pelayaran dan Perdagangan Gorontalo Abad ke18 dan 19. Yogyakarta: Kepel Press.
Henley, David E. F. 2005. Fertility, Food, and Fever. Population, Economy and Environment in North and Central Sulawesi, 16001930. Leiden: KITLV Press. . 1996. Nationalism and Regionalism in a Colonial Context: Minahasa in the Dutch East Indies. Leiden: KITLV Press.

Jumat, Gani. 1992. Nasionalisme Ulama: Pemikiran Politik Kebangsaan Sayyid Idrus bin Salim al-Jufry, 1896-1969. Jakarta: Kementerian Agama RI.

Kaptein, Nico J. G. 2017. Islam, Kolonialisme dan Zaman Modern di Hindia Belanda, Biografi Sayyid 'Uthman (1822-1914). Yogyakarta: Suara Muhammadiyah.

Lapian, A.B. 1974. Kata Pengantar Teori Mahan dan Sejarah Kepulauan Indonesia. Jakarta: Bharata. 2009. Orang Laut, Raja Laut, dan Bajak Laut: Studi Kawasan Laut Sulawesi Abad XIX. Jakarta: Komunitas Bambu.

Makkelo, Ilham Daeng. 2010. Kota Seribu Gereja: Dinamika Keagamaan dan Penggunaan Ruang di Manado. Yogyakarta: Ombak.

Milone, P. Dublin. 1966. Urban Areas in Indonesia: adminsitrative and Census Concepts. Berkeley: University of California. 
Handep Jurnal Sejarah dan Budaya Vol. 4, No. 1, Desember 2020, hlm. 61-86

Moelsbergen, E. C. Goedee. 1928. Geschidenis van de Minahasa tot 1829. Landsarchivaris: Landskrukkerij-Welterverden.

Parengkuan, F. E. W. et al. 1983. Sejarah Sosial Sulawesi Utara. Jakarta: Depdikbud.

Poelinggoman, Edward L. 2012. Bahan ajar Sejarah Maritim. Makassar: LKKP UNHAS.

Purba, Jhon R. 2018. Pelayaran dan Perdagangan Kopra di Gorontalo (1888-1942). Yogyakarta: Amara Books.

Rasyid, L. A., Supriadi, S., \& Aisa, S. 2018. "Pemikiran dan Peranan Sayyid Idrus Bin Salim Aljufri terhadap Perkembangan Pendidikan Islam di Manado." Journal of Islamic Education Policy Vol. 3, No. 1: 35-43.

Riedel, J. G. F. 1869. "Het Landschappen Holontaloe, Limoetoe, Bone, Boalemo en Kattinggola of Andagila." Tijdschrift van Bataavish Genootschaap Voor Indische Taal, Land, en Volkenkunde (TBG), vol. XIX: hlm. 45-153.

Safran, William. 1991. Diaspora in Modern Societies: Myth of Homeland and Return Diaspora: A Journal of Transnational Studies 1 (1):83-99.

Santoso, M. Imam. Oktober 2014. "Diaspora: Migrasi Internasional dan Kewarganegaraan Ganda."
Makalah Pada Seminar oleh Fakultas Hukum Udayana bekerjasama dengan Indonesia Diaspora Network. Universitas Udayana, Bali.

Schouten, M. J. C. 1998. Leadership and Social Mobility in Southeast Asian Society, Minahasa 16771983. Leiden: KITLV.

Staatsblad van Nederlandsch Indie 1824, 14 Juni 1824. No. 10. Waarbij woordt bepaald, dat de Sangeische, talantsche of andere voor her onder Ternate, gestaan hebbende Eilanden, ten noorden van Menado gelegen, voortan een gedeelte van den Residentie Menado zullen uitmaken, SGravenhage: ter Drukkerij van A. D. Schinkel.

Staatsblad van Nederlandsch Indie 1824. No. 28a. 1939. Waarbij wordt bepaald, dat de Sangeische, talantsche of andere voor her onder Ternate, gestaan hebbende Eilanden, ten noorden van Menado gelegen, voorstan een gedeelte van den Residentie Menado zullen uitmaken., S-Gravenhage: ter Drukkerij van A. D. Schinkel.

Staatsblad van Nederlandsch Indie het jaar 1847, No. 32, 29 April 1847. Bepaling omtrent de verstrekking van meer amfioen aan de pachters, dan de hoeveelheid welke door het tijdens de verpachting geboden is, Batavia: ter s'lands-Dukkerij. 
Staatsblad van Nederlandsch Indie 1919 No. 64 Decentralisatie Instelling van een plaatslijken raad voor de Minahassa. Afzondering van geldmiddelen voor den plaatselijken raad van de Minahassa uit de algemeene geldmiddelen van NederlanschIndie. Landskrukkerij: Welterverden, 1920.

Steenbrink, Karel. 2017. Kaum Kolonial Belanda dan Islam di Indonesia, terj. Suryan A. Jamrah, Yogyakarta: Gading Publishing.

Stroomberg, J. 2018. Hindia Belanda, 1930. Terj. Heri Apriyono, Yogyakarta: IRCiSOD.

Supit, Bert. 1988. Minahasa dari Amanat Watu Pinawetengan Sampai Gelora Minawanua, Jakarta: Sinar Harapan.

Suwondo, Bambang. 1977/1978. Sejarah Daerah Sulawesi Utara. Manado: Pusat Penelitian Sejarah dan Budaya Depdikbud.

Sulistiyono, Singgih Tri. 1997. $D i$ Bawah Bayang-bayang Ekonomi Agraris: Dinamika Sektor Pelyaran Pribumi di Jawa Memasuki Abad ke-XX. Jakarta: Depdikbud, Proyek Inventarisasi dan Dokumentasi Sejarah Nasional.

Taulu, H. M. 1977. Sejarah Masuknya Islam Agama Islam di Sulawesi Utara dengan Perkembangan Ikatan Kebudayaan dan Hukum
Adat Daerah terutama Minahasa. Manado: PD3K.

Tumbel, Erni Heni. 1996. "Sejarah Dewan Perwakilan Rakyat Kota Manado Tahun 1919-1971.” Skripsi, Fakultas Ilmu Budaya: Universitas Sam Ratulangi, Manado.

Turner, Jack. 2011. Sejarah Rempah: Dari Eksotisme Sampai Imprealisme. Terj. Julia Absari, Jakarta: Komunitas Bambu.

Ulaen, Alex J. 2018. Pelayaran dan Perniagaan Kopra di Wilayah Karesidenan Manado. Afdeeling Manado (1910-1940). Yogyakarta: Amara Books.

Valentijn, Francois. 1724. Oud en Nieuw Oost-Indien Vervattend en Naaukeurige en uitvorige Verhandeling van Nederland Mogenthyed in die Gewesten Benevens, Bechryvinge van Ambonia, vol III. Dordecht \& Amsterdam: Joannes van Braam \& Gerard Onde de Linden.

Van den Berg, L. W. C. 2010. Orang Arab di Nusantara. Terj. Rahayu Hidayat. Jakarta: Komunitas Bambu.

Van der Crab, P. 1862. De Moluksche Eilanden: Reis van Z.E. den Gouverneur-Generaal C.F. Pahud door den Molukschen archipel., Batavia: Lange en Co. 
Van der Endt, Adr. 1921. De Zending in Bolaang Mongondow. Leiden: Zendingsbureau te Oegstgeest.

Van Leur, J. C. 2015. Perdagangan dan Masyarakat Indonesia: Esai-Esai tentang Sejarah Sosial dan Ekonomi Asia.Yogyakarta: Ombak.

Vickers, Adrian. 2013. A History of Modern Indonesia. Second Edition, USA: Cambridge University Press.

Vlekke, Bernard H.M. 2016. Nusantara: Sejarah Indonesia. Terj. Samsudin Berlian. Jakarta: KPG.

Wiersma, J. N. 1880. "Een brief uit de Minahassa" De Indische Gids (IG), Tweede Jaargang II: hlm. 820-832.

Wigboldus, Jouke S. 1987. "A History of the Minahasa c. 1613-1680." Archipel, Vol. 34: 63-101. 